\title{
Characterization of a Mouse Model of Hyperglycemia and Retinal Neovascularization
}

\author{
Elizabeth P. Rakoczy, ${ }^{*}$ Ireni S. Ali Rahman, ${ }^{*}$ \\ Nicolette Binz, ${ }^{\dagger}$ Cai-Rui Li, ${ }^{* \ddagger}$ Nermina N. Vagaja, ${ }^{*}$ \\ Marisa de Pinho, ${ }^{\dagger}$ and Chooi-May Lai* \\ From the Centre for Ophthalmology and Visual Science," The \\ University of Western Australia, Crawley, Australia; Molecular \\ Ophthalmology, ${ }^{\dagger}$ Lions Eye Institute, Nedlands, Australia; and the \\ Ophthalmology Department, ${ }^{\ddagger}$ Hospital of Dali University, Yunnan \\ Province, China
}

One of the limitations of research into diabetic retinopathy is the lack of suitable animal models. To study how the two important factors-hyperglycemia and vascular endothelial growth factor-interact in diabetic reti-

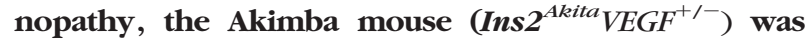
generated by crossing the Akita mouse (Ins2 ${ }^{\text {Akita }}$ ) with the Kimba mouse $\left(\mathrm{VEGF}^{+/+}\right) . \mathrm{C} 57 \mathrm{Bl} / 6$ and the parental and Akimba mouse lines were characterized by biometric measurements, histology, immunohistochemistry, and Spectralis Heidelberg retinal angiography and optical coherence tomography. The Akimba line not only retained the characteristics of the parental strains, such as developing hyperglycemia and retinal neovascularization, but developed higher blood glucose levels at a younger age and had worse kidney-body weight ratios than the Akita line. With aging, the Akimba line demonstrated enhanced photoreceptor cell loss, thinning of the retina, and more severe retinal vascular pathology, including more severe capillary nonperfusion, vessel constriction, beading, neovascularization, fibroses, and edema, compared with the Kimba line. The vascular changes were associated with major histocompatibility complex class $\mathrm{II}^{+}$cellular staining throughout the retina. Together, these observations suggest that hyperglycemia resulted in higher prevalences of edema and exacerbated the vascular endothelial growth factordriven neovascular and retinal changes in the Akimba line. Thus, the Akimba line could become a useful model for studying the interplay between hyperglycemia and vascular endothelial growth factor and for testing treatment strategies for potentially blinding complications, such as edema. (Am J Pathol 2010, 177:2659-2670; DOI: 10.2353/ajpath.2010.090883)
Diabetes is widely recognized as one of the leading causes of death and disability and is the fifth-leading cause of death by disease in the United States. ${ }^{1}$ Diabetes is associated with long-term complications that affect almost every part of the body, often leading to blindness, cardiovascular disease, kidney failure, and nerve damage.

The Ins $2^{\text {Akita }}$ (Akita) mouse ${ }^{2-4}$ is a naturally occurring diabetes model that carries a dominant mutation in the Mody4 locus on chromosome 7 in the insulin 2 gene. The heterozygous male mice develop hyperglycemia and hypoinsulinemia at 4 weeks postnatal and progress to develop the well-known signs of diabetes. They exhibit signs similar to early pathophysiological changes of diabetic complications, ${ }^{5-11}$ but fail to develop any of the advanced stages of these complications. Analysis of retinae of Ins $2^{\text {Akita }}$ mice ${ }^{5}$ showed early neuronal changes, increased vascular permeability, a modest increase in acellular capillaries, increased leukostasis, a thinner inner plexiform layer, and amacrine and ganglion cell loss. ${ }^{12}$ Although these changes are associated with the early stages of diabetic retinopathy (DR), they fall short of the proposed target for a DR animal model, which should have capillary and neuronal loss, capillary obliteration and dropout, retinal edema, and preretinal neovascularization (preRNV; Animal Models of Diabetic Complications Consortium, http://www.amdcc.org/shared/retinopathyvalidation.aspx; last accessed on August 23, 2010).

The trVEGF029 (Kimba) mouse model, in which photoreceptors transiently overexpress human vascular endothelial growth factor (hVEGF), ${ }^{13-14}$ has a slower and less destructive form of neovascularization ${ }^{15}$ than previously described models. ${ }^{16}$ The Kimba model features

Supported by the Juvenile Diabetes Research Foundation (USA), National Health and Medical Research Council, and Australia (project grant 353599) and WestPac grant-in-aid (Australia). N.B. receives financial support from the Lions Save-Sight Foundation of Western Australia through the foundation's Brian King Postdoctoral Research Fellowship. I.S.A.R. is the recipient of the Ministry of Education's Brunei Darussalam, Postgraduate Research Scholarship.

Accepted for publication July 8, 2010.

None of the authors disclosed any relevant financial relationships.

Address reprint requests to Elizabeth P. Rakoczy, Ph.D., Lions Eye Institute, 2 Verdun St, Nedlands, WA 6009, Australia. E-mail: rakoczy@ cyllene.uwa.edu.au. 
hVEGF production, which peaks at around 10 days postnatal and gradually decreases to an only slightly elevated level by 6 weeks postnatal. ${ }^{14-15}$ Despite transient hVEGF up-regulation, the short-term presence of elevated hVEGF induces vascular permeability, capillary nonperfusion/ dropout, microaneurysms, RNV, and occasional hemorrhages. ${ }^{15,17}$ The Kimba model has several vascular changes associated with DR but, crucially, this model is not on a hyperglycemic background.

To date, other rodent diabetes models, whether transgenic, naturally occurring or induced, have failed to develop advanced stages of retinal complications regardless of the age of onset or the duration of hyperglycemia. Thus, generation of a model that develops retinal vascular changes similar to those presented in DR would represent a significant advance for DR research. This article describes the generation of a mouse model that presents with RNV on a hyperglycemic background. We crossbred the Akita with our Kimba mice ${ }^{13,15}$ resulting in a model that allows investigation into the interplay between high blood glucose levels (BGLs) and VEGF-induced retinal pathology.

\section{Materials and Methods}

\section{Animal Husbandry and Anesthesia}

All procedures were performed in accordance with the Association for Research in Vision and Ophthalmology statement for use of animals in ophthalmic and vision research and with approval from the Animal Ethics Committee of The University of Western Australia. Mice were housed, fed, ${ }^{18}$ and anesthetized ${ }^{19}$ as previously described. All studies were performed on young (8 weeks postnatal) and old ( $25 \pm 1$ week postnatal) male mice.

\section{Generation of Double Mutant Akimba Mouse Model}

Heterozygous Kimba $\left(V_{E G F^{-/+}}\right)$mice were generated as described previously. ${ }^{15,17}$ Homozygous Kimba $\left(\mathrm{VEGF}^{+/+}\right)$ mice were mated with mice heterozygous for the Akita spontaneous mutation (Ins2 $2^{\text {Akita }}$ ), purchased from the Jackson Laboratory (Bar Harbor, ME), to generate Kimba or Akimba (Ins2 ${ }^{\text {Akita }} V E G F^{+/-}$) mice. Both Kimba and Akita mice are on a C57BL/6 background. Only males were used for the studies because disease progression in females is slower and less uniform.

\section{Genotyping}

DNA was isolated from tail clips by using the Wizard Genomic DNA Purification Kit (Promega, Madison, WI). Genotyping of Kimba mice was carried out as previously described. ${ }^{15,17}$ Akita mice were genotyped for the Ins2 gene as described (Jackson Laboratory). Akimba mice were genotyped by using protocols for both Kimba and Akita mice.

\section{Blood Glucose Measurements}

Mice were fasted from 7:00 AM to 1:00 PM as per Animal Models of Diabetic Complications Consortium guidelines. BGL was determined by using Accu-Check Performa blood glucose meter (Roche Diagnostic, Mannheim, Germany) with a range of 0.6 to $33.3 \mathrm{mmol} / \mathrm{L}$. Readings above $33.3 \mathrm{mmol} / \mathrm{L}$ were treated as $33.3 \mathrm{mmol} / \mathrm{L}$ during data analysis. The meter was calibrated for each batch of test strips. Total kidney-body weight (KBW) ratios were calculated according to Animal Models of Diabetic Complications Consortium protocols.

\section{Glycated Hemoglobin Level}

Glycated hemoglobin (HbA1c) in Akita and Akimba mice was determined by using Siemens' DCA 2000+ Analyzer (Siemens Medical Solutions Diagnostics, Vic., Australia), a diabetes point-of-care system validated for use in mice as an alternative to high-performance liquid chromatography. ${ }^{20}$

\section{Clinical Ophthalmic Photography}

Imaging of the eye was performed by using the combined confocal scanning laser ophthalmoscope and spectral domain optical coherence tomography (OCT) imaging device (Spectralis Heidelberg retinal angiography and OCT; Heidelberg Engineering, Heidelberg, Germany) with a 25-diopter lens fitted on a 30-degree angle lens. The pupils of anesthetized mice were dilated with tropicamide eye drops (Mydriacyl; Alcon) Laboratories, NSW, Australia before image acquisition. Mice were injected intraperitoneally with 50 $\mu \mathrm{l}$ of $10 \%$ sodium fluorescein. A custom-made contact lens (refractive index, 1.51; radius of curvature, $1.70 \mathrm{~mm}$; diameter, $3.2 \mathrm{~mm}$; Cantor-Nissel, Northamptonshire, UK) was placed on the mouse eye to collect spherical optical aberration and to prevent dehydration of the cornea during imaging. For fluorescein angiography $(F A)$, the Spectralis HRA+OCT was operated in the fluorescence mode with the excitation light provided by the 488-nm Argon laser. All images were acquired by using the automatic real-time mode to track eye movements in real time and stabilize the OCT scan on the retina. Sequences of B-scans obtained at a 30-degree field of view centered on the optic disk were acquired to generate a volume scan. Retinal thickness was calculated as an average of the volume scan values. Images were analyzed on the Heidelberg Eye Explorer Software 1.5.12 with the Spectralis viewing module 3.1.0.

\section{Histology}

After euthanasia with pentobarbital (Lethabarb, Virbac, NSW, Australia), eyes were enucleated and fixed for 4 hours in $4 \%$ neutral buffered formalin before paraffin embedding. The eyes were sectioned sagitally and sections passing through the optic nerve and center of the cornea were stained with H\&E or PAS for light microscopy. Comparative retinal morphology of the different mouse strains was based on thickness of the neural 
A

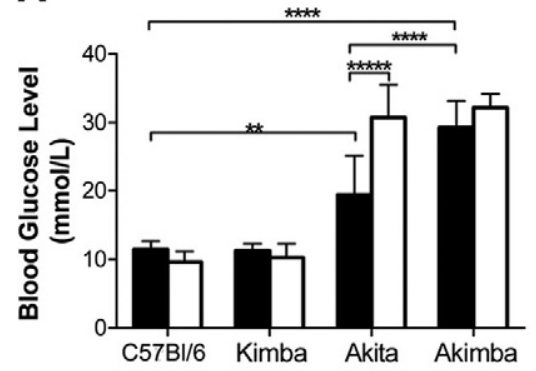

B

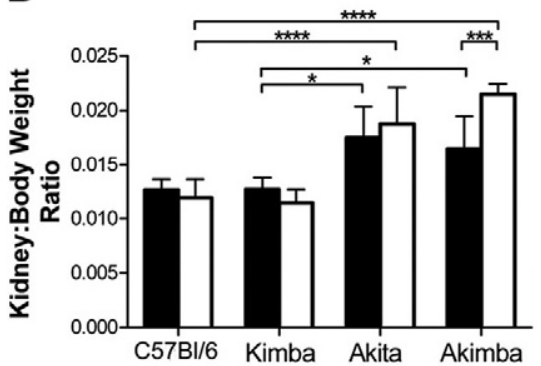

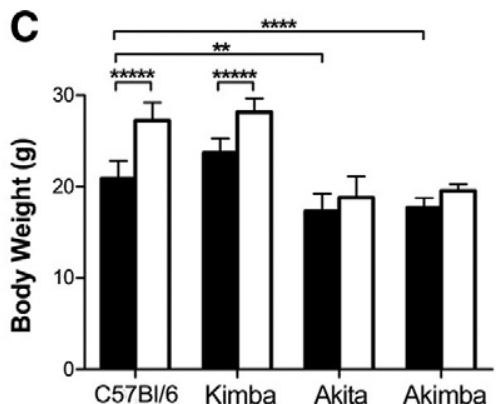

Figure 1. Mean fasted blood glucose levels (A), kidney-body weight ratios (B), and total body weight (C) in young and old male mice of all four genotypes. Black bars $=$ young animals; white bars $=$ old animals. ${ }^{*} P<0.05 ;{ }^{* * *} P<0.01 ;{ }^{* * * *} P<0.005 ;{ }^{* * * * *} P<0.001 ;{ }^{* * * * * *} P<0.0001$.

retina, photoreceptor layer thickness, and number of ganglion cells present over a 170- $\mu \mathrm{m}$ linear distance on both sides of the optic nerve. One eye per mouse $(n=6$ to 8) from each experimental group was used, and a total of 5 to 10 measurements per eye was taken for analysis.

\section{Immunohistochemistry}

For visualization of retinal vasculature, deparaffinized sections of the eye were processed and labeled with biotinylated isolectin-IB4 as described previously. ${ }^{14}$ For detection of immune cells, enucleated eyes were postfixed in $2 \%$ paraformaldehyde for 2 hours at room temperature. The retinae were dissected out and washed in PBS. After incubation in $20 \mathrm{mmol} / \mathrm{L}$ EDTA tetrasodium at $37^{\circ} \mathrm{C}$ for 30 minutes, the specimens were saturated with PBS containing $0.3 \%$ Triton- $X$ and $2 \%$ bovine serum albumin at room temperature for 1 hour and then incubated overnight at $4^{\circ} \mathrm{C}$ with anti-major histocompatibility complex (MHC) class II antibody (M5/114; 1:200; BD Pharmingen, San Diego, CA). Secondary and tertiary antibody incubations were at room temperature: biotinylated goat anti-rat IgG (1:100; GE Health care, Piscataway, NJ) for 2 hours, then streptavidin Alexa Fluor 568 (1:100; Molecular Probes, Eugene, OR) for 30 minutes. For tissues in which vasculature was also labeled with rhodamine concanavalin $A,{ }^{21}$ the same staining protocol was followed, but the tertiary antibody used was streptavidin Alexa Fluor 488 (1:100; Molecular Probes). Labeled whole mounts and sections were evaluated with epiflurorescence microscopy (Olympus, BX60, Tokyo, Japan).

\section{VEGF Protein Quantitation}

Mouse VEGF (mVEGF) and hVEGF protein levels in eyes were determined by enzyme-linked immunosorbent assay as previously described. ${ }^{18}$

\section{Data Analyses}

Data were analyzed by one-way or two-way analysis of variance followed by Tukey's Multiple Comparison Test at a 5\% significance level by using GraphPad Prism version 4.01 for Windows (GraphPad Software, San Diego, CA) for comparisons across all four genotypes. Student's $t$ test was used to assess changes in a single parameter over time within a genotype $(\alpha=0.05)$. Data are presented as mean $\pm \mathrm{SD}$.

\section{Results}

\section{Physical Comparison of Mouse Lines}

At birth all mice were normal in appearance and behavior. The average number of pups per litter was as follows: Akita: $6.1 \pm 2.4$; Akimba: $6.5 \pm 2.1$; and Kimba: $6.2 \pm$ 2.5 , which was similar to $\mathrm{C} 57 \mathrm{Bl} / 6$ mice $(6.8 \pm 0.1){ }^{22}$ Kimba mice have a mean lifespan similar to C57BI/6 mice (690 days), whereas the Akimba mice have a mean lifespan similar to the Akita mice (305 days; Jackson Laboratory).

\section{Blood Glucose Level}

There was no statistically significant difference in mean BGL between young C57BI/6 and Kimba mice (11.5 \pm 1.3 and $11.3 \pm 1.0 \mathrm{mmol} / \mathrm{L}$, respectively; $P>0.05$; Figure $1 \mathrm{~A})$. Mean BGL in young Akita mice (19.4 $\pm 5.7 \mathrm{mmol} / \mathrm{L})$ was significantly higher than in age-matched C57Bl/6 $(P<0.01)$ and Kimba mice $(P<0.001$; Figure 1A). The surprising result was the significantly higher mean $B G L$ in young Akimba mice (29.3 $\pm 3.9 \mathrm{mmol} / \mathrm{L})$ compared with young Akita mice $(P<0.001)$. Mean $\mathrm{BGL}$ remained normal and unchanged in old $\mathrm{C} 57 \mathrm{BI} / 6$ and Kimba mice $(P>0.05)$. In Akimba mice, there was a slight, but not statistically significant, increase in mean BGL to $32.2 \pm$ $2.0 \mathrm{mmol} / \mathrm{L}(P>0.05)$. In the Akita mice, there was a statistically significant increase in mean BGL to $30.9 \pm$ $4.6 \mathrm{mmol} / \mathrm{L}$ in old mice $(P<0.0001)$. The mean $B G L$ in old Akita mice was similar to those of young and old Akimba mice.

The mean $\mathrm{HbA} 1 \mathrm{c}$ level was $4.4 \%$ in young $\mathrm{C} 57 \mathrm{Bl} / 6$ and Kimba mice and $4.3 \%$ in old $\mathrm{C} 57 \mathrm{BI} / 6$ and Kimba mice. Thus, as expected, there was no age-dependent increase in mean $\mathrm{HbA1c}$ level in the normoglycemic C57BI/6 and Kimba mice. In contrast, mean $\mathrm{HbA} 1 \mathrm{c}$ level in young Akita (6.7\% \pm 0.6$)$ and young Akimba (7.05\% \pm 1.3) mice increased to $11.5 \% \pm 0.3$ and $11.2 \% \pm 1.4$, respectively, in the old hyperglycemic mice. 
Total Kidney-Body Weight Ratios

There was no difference in mean KBW ratios (Figure 1B) between the young $\mathrm{C} 57 \mathrm{BI} / 6$ and Kimba mice (0.013 \pm 0.001 and $0.013 \pm 0.001$, respectively; $P>0.05$ ), and between young Akita and Akimba mice $(0.018 \pm 0.003$ and $0.017 \pm 0.003$, respectively; $P>0.05$ ). However, in young mice, mean KBW ratios were significantly different between Kimba and Akita $(P<0.01)$ and between Kimba and Akimba $(P<0.01)$. In old mice, the difference in

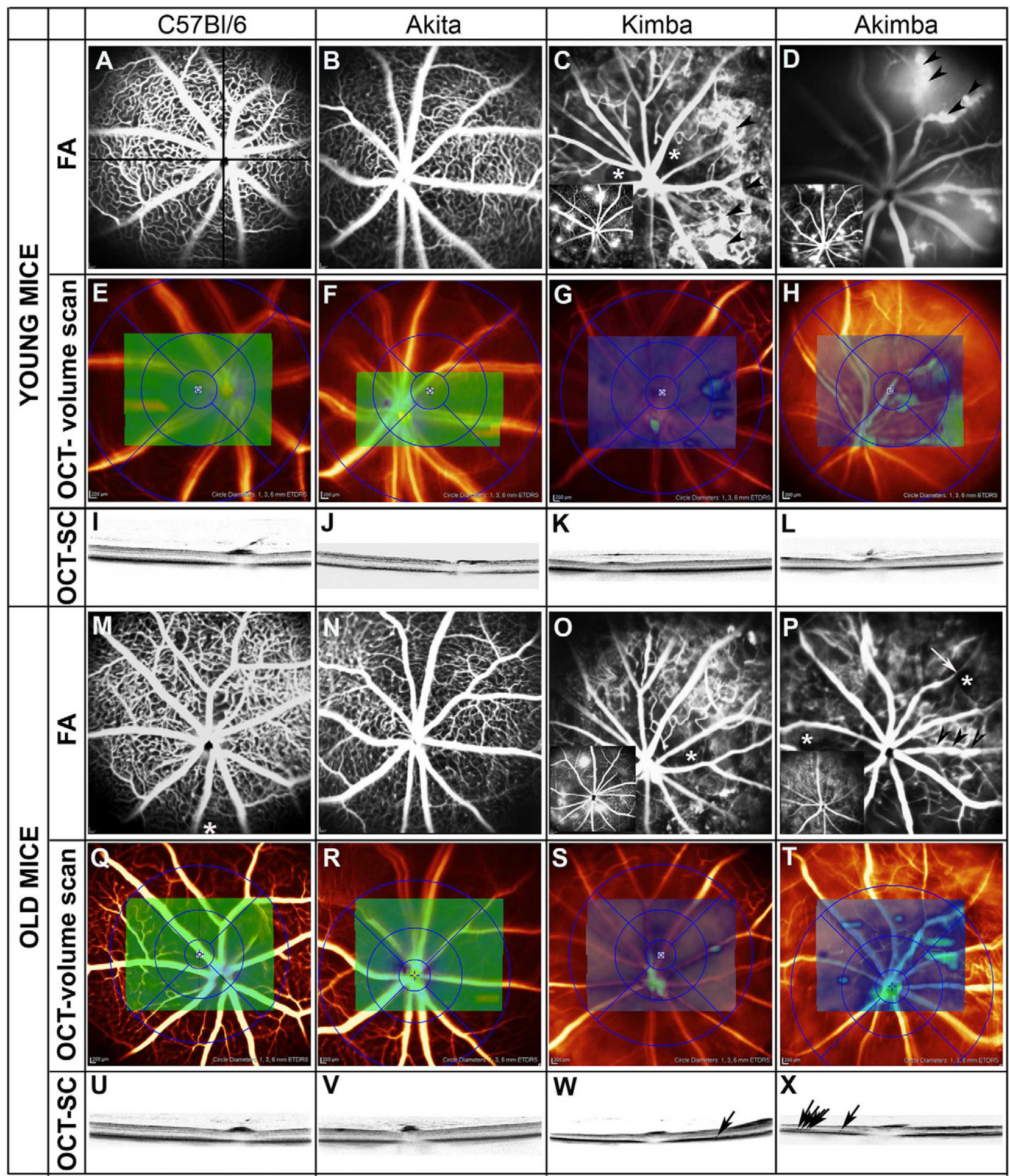

○ 
mean KBW ratios between normoglycemic C57B//6/ Kimba and hyperglycemic Akita/Akimba was significant $(P<0.001)$, but there was no statistically significant difference between Akita and Akimba mice $(P>0.05)$. There was, however, a significant age-dependent increase in mean KBW ratio in the Akimba mice $(P<0.005$; Figure 1B).

\section{Body Weight}

Mean body weights were similar in normoglycemic young C57BI/6 $(20.9 \pm 2.0 \mathrm{~g})$ and Kimba $(23.7 \pm 1.6 \mathrm{~g})$ mice $(P<0.05)$. The mean body weights of the hyperglycemic young Akita $(17.3 \pm 2.0 \mathrm{~g})$ and Akimba $(17.7 \pm 1.1 \mathrm{~g})$ mice were significantly lower $(P<0.01)$ than those of young $\mathrm{C} 57 \mathrm{BI} / 6$ mice, but they were similar to each other (Figure 1C). There was an age-dependent increase in mean body weights of C57BI/6 $(P<0.0001)$ and Kimba $(P<0.0001)$, but not in Akita $(P>0.05)$ and Akimba $(P>$ $0.05)$ mice. In both young and old mice, there was a significant difference in mean body weight between C57BI/6 and Akita or Akimba $(P<0.01)$ and between Kimba and Akita or Akimba mice $(P<0.001)$, with body weights of the hyperglycemic mice always significantly lower than in the normoglycemic C57BI/6 and Kimba mice.

\section{Clinical and Morphometric Analyses of Mouse Eyes}

Images from FA and OCT (volume and section scans) of a representative mouse from each genotype are presented in Figure 2. Comparison between Kimba and Akimba mice was performed by using littermates to ensure uniformity in terms of age and parental influence. Analysis of retinal vessels by FA of young and old C57BI/6 mouse eyes showed even calibre retinal vessels radiating from well-defined optic nerve heads (Figure 2, A and M). A dense capillary network was present and flu-

Figure 2. Fluorescein angiograms showing the differences in retinal vasculature between young $\mathrm{C} 57 \mathrm{Bl} / 6(\mathbf{A})$, Akita $(\mathbf{B})$ Kimba $(\mathbf{C})$, and Akimba mice. $\mathrm{C} 57 \mathrm{Bl} / 6$ (A) and Akita (B) mice have sharply defined retinal vessels and retinal capillary network with retinal vessels radiating from the optic nerve. Kimba (C, arrowheads, inset) and Akimba (D, inset) mice have foci of fluorescein leakage and microvascular changes such as capillary dropout/ nonperfusion (C, asterisks) and microaneurysm (D, arrows). OCT volume scans show the thickness of the retina around the optic nerve of $\mathrm{C} 57 \mathrm{Bl} / 6(\mathbf{E})$, Akita (F), Kimba (G), and Akimba (H). The homogenous green coloration denotes that thickness of the retina of young $\mathrm{C} 57 \mathrm{Bl} / 6$ and Akita mice (230 to $280 \mathrm{~mm}$ ) is even. The retina of young Kimba (G: 180 to $250 \mu \mathrm{m}$ ) and Akimba (H: 50 to $250 \mu \mathrm{m}$ ) are of uneven thickness. OCT section scans (OCT-SCs; I-L) of the four different mouse strains show the thickness of the retina across the optic nerve. Fluorescein angiograms of the same mouse from each strain at 24 weeks postnatal show no change in retinal vasculature of $\mathrm{C} 57 \mathrm{Bl} / 6(\mathbf{M})$ and Akita (N) mice. There were less foci of fluorescein leakage in Kimba $(\mathbf{O}$, inset) and Akimba (P, inset) mice. Microvascular changes such as capillary dropout/nonperfusion (O and $\mathbf{P}$ : asterisks) and venous beading (P: arrows). OCT volume scans showed no change in retinal thickness of C57Bl/6 (Q) and Akita (R) mice but further thinning of the retina of Kimba (S) and Akimba (T) mice were observed. OCT section scans of $\mathrm{C} 57 \mathrm{Bl} / 6$ (U), Akita (V), Kimba (W), and Akimba (X) mice confirmed the absence of change in retinal thickness of $\mathrm{C} 57 \mathrm{Bl} / 6$ and Akita mice and further thinning of the retina of Kimba and Akimba mice. Dense spots are new vessels seen in the old Kimba (W, arrow) and Akimba ( $\mathbf{X}$, arrows) mice. The thickness of the retina is indicated by the different colors in the scale provided.
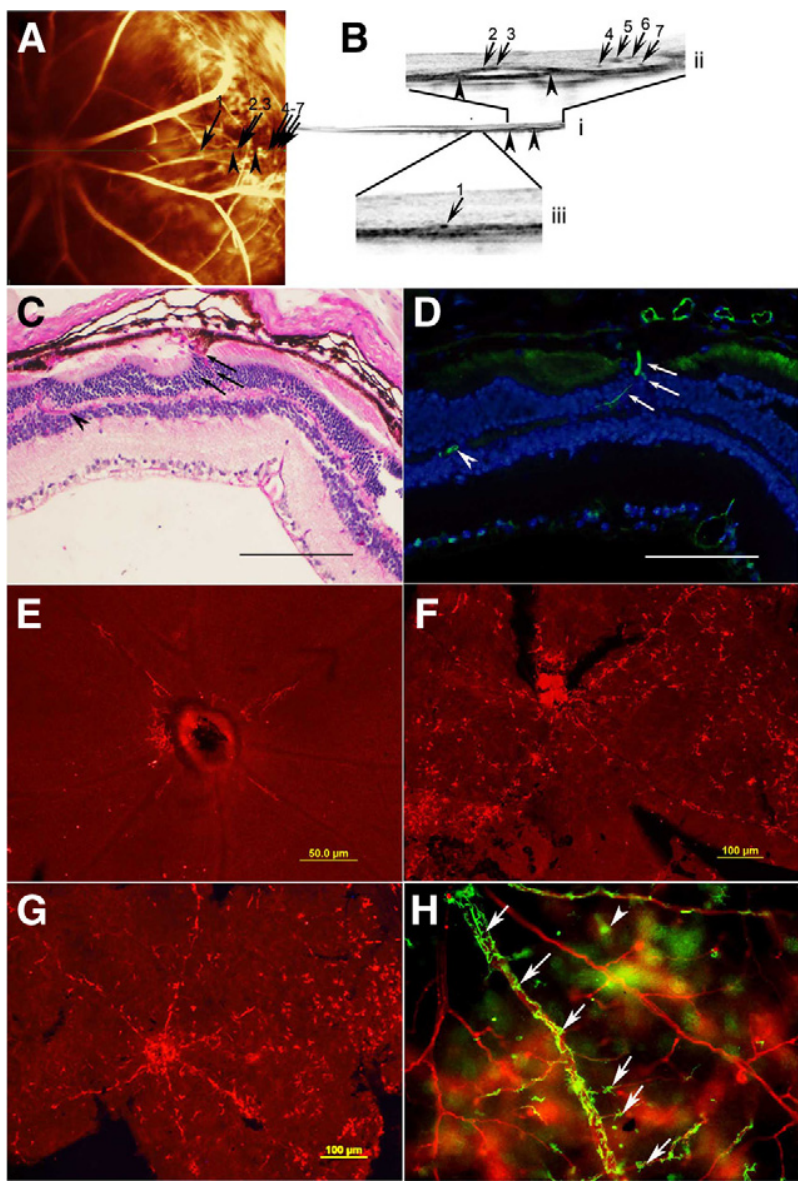

Figure 3. FA and corresponding OCT scan of a young Akimba mouse, showing the retinal vasculature $(\mathbf{A})$ and the cross section $(\mathbf{B}, \mathbf{i})$ of the retina Figure $\mathbf{B}$ (i) is magnified to show edema (ii) and blood vessels (ii and iii) in the outer nuclear layer. Numbered arrows in (A) denote location of blood vessels observed in the outer nuclear layer from OCT scan $(\mathbf{B}, \mathbf{i})$. Arrowheads in $\mathbf{A}$ point to where the edema is located from OCT scan (B, i and ii). Paraffin-embedded sections of an Akimba mouse eye stained with PAS (C) and labeled with IB-4 (D). Arrows denote vessels transgressing the inner nuclear layer. Scale bar for $\mathbf{C}$ and $\mathbf{D}=165 \mu \mathrm{m}$. MHC Class II labeling of Akita (E), Kimba (F), and Akimba (G and $\mathbf{H})$ retinal flat mounts show rise in $\mathrm{MHC}$ Class $\mathrm{II}^{+}$cells in Kimba and Akimba retinal flat mounts. MHC Class $\mathrm{II}^{+}$ dendriform cells (arrows) are found around rhodamine concanavalin A-labeled vessels $(\mathbf{H})$.

orescein leakage was absent in any of the C57BI/6 mouse eyes analyzed by FA (Figure 2, A and M). The retinae of young (250.5 $\pm 7.6 \mu \mathrm{m}, n=30)$ and old (242.7 $\pm 8.4 \mu \mathrm{m}, n=30)$ C57BI/6 mouse eyes were of comparable thickness as indicated by the even green coloration throughout the areas of OCT volume scans (Figure 2, E and Q) and section scans (Figure 2, L and U). The Akita mice presented similar vascular features to $\mathrm{C} 57 \mathrm{BI} / 6$ (Figure 2, B and $\mathrm{N}$ ) and the retinal thickness was also comparable (young: $254.4 \pm 5.4 \mu \mathrm{m}$; old: $242.2 \pm$ $11.2 \mu \mathrm{m}$ mouse eyes, $n=30$; Figure 2, F and R). Section scans passing through the optic nerve also showed that there was no difference in retinal thickness between young and old $\mathrm{C} 57 \mathrm{BI} / 6$ (Figure 2, L and $\mathrm{U}$ ) and young and old Akita (Figure 2, J and V) mice. Volume scan values ranged from 230 to $280 \mu \mathrm{m}$ in young and old C57BI/6 and Akita mice. In contrast, changes were observed in eyes of young and old Kimba (Figure 2, C, G, K, $\mathrm{O}, \mathrm{S}$, and $\mathrm{W}$ ) and Akimba (Figure 2, D, H, L, P, T, and $\mathrm{X}$; 
A

\section{Grade}

Normal

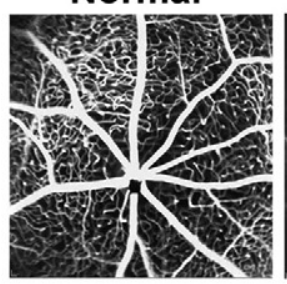

0

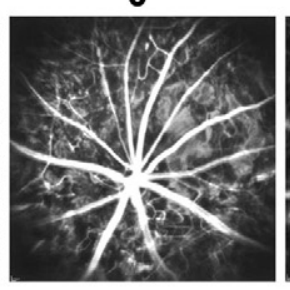

1

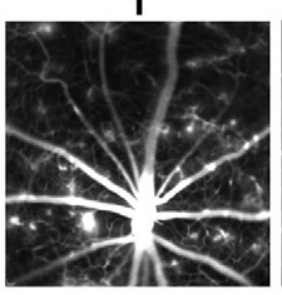

2

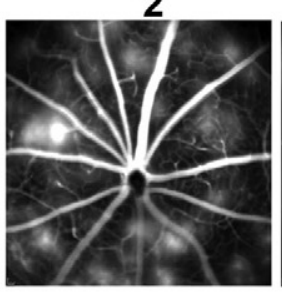

3

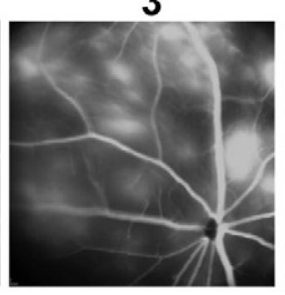

4

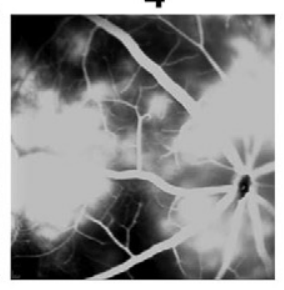

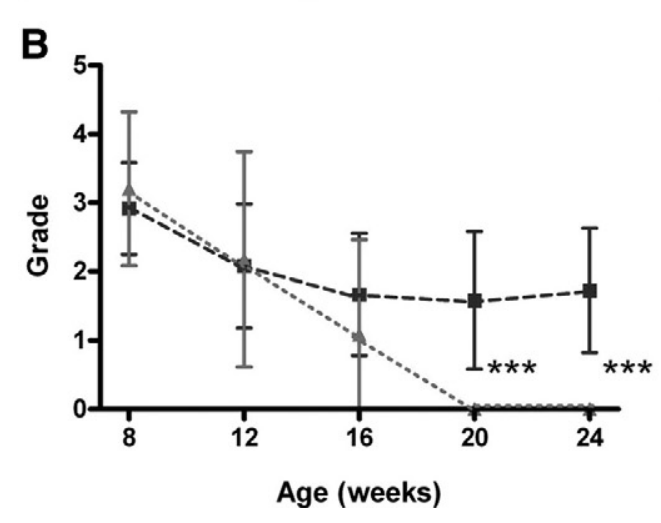

Figure 3A) mice. FA consistently showed the presence of sparse capillary beds and fluorescein leakages in Kimba ( $n=32$; Figure 2, $\mathrm{C}$ and $\mathrm{O}$ insets) and Akimba ( $n=40$; Figure 2, D and $P$, insets) mice. There appeared to be more foci of and more extensive fluorescein leakage in the eyes of young mice of both genotypes (Figure 2, C and D, insets; grading of 2 to 4 in Figure 4). Furthermore, Kimba and Akimba mice demonstrated tortuous vessels (data not shown), microaneurysms (Figure 2, C and D, arrowheads), venous beading (Figure 2P, arrowheads), capillary dropout and nonperfusion (Figure 2, C, O, and $P$, asterisks), vessel dilatation (data not shown), and vessel attenuation (Figure 2P, arrow). The mean retinal thickness profiles varied as a function of age and glycemic status, ie, between eyes of young $(183.7 \pm 23.6 \mu \mathrm{m})$ and old $(151.1 \pm 25.1 \mu \mathrm{m} ; P<0.001) \mathrm{Kimba}$ and young $(203.4 \pm 38.0 \mu \mathrm{m})$ and old $(155.2 \pm 10.6 \mu \mathrm{m} ; P<0.01)$ Akimba mice. Retinal thickness based on volume scans ranged from 150 to $200 \mu \mathrm{m}$ in young Kimba mice (Figure 2G) and from 80 to $150 \mu \mathrm{m}$ in old Kimba (Figure 2S) mice. Well-defined areas of regional thickening in these models are demonstrated by green patches on volume scans. In young (Figure 2H) and old Akimba (Figure 2T) mice, retinal thickness on volume scans ranged between 80 and $280 \mu \mathrm{m}$ and 80 and $150 \mu \mathrm{m}$, respectively. In section scans, dense spots were observed in the outer nuclear layer of Kimba (Figure 2W, arrow) and Akimba (Figure 2X, arrows) mice. As vessels are not present in the outer nuclear layer of normal eyes, these dense spots represent new blood vessels. Edema (between arrowheads, Figure 3, Bi and $\mathrm{Bii}$ ) was observed in the peripheral part of the retinae of 27 of $40(67 \%)$ young Akimba and 14 of $40(36 \%)$ old Akimba mice. New vessels usually localized in the outer nuclear layer and in association with retinal edema (Figure 3, Bi-iii). The vasculature detected by OCT (Figure 3B) was correlated to vessels in the fluorescein angiogram (Figure $3 \mathrm{~A}$ ) by using numbered arrows.

Fluorescein leakage in the Kimba and Akimba mice was graded by two masked observers based on the scale shown in Figure 4A and presented in Figure 4B. From the grading, younger Kimba and Akimba mice ( 8 to 16 weeks postnatal) did not show any significant difference in fluorescein leakage $(P>0.05)$. However, the grading in older Kimba and Akimba mice (20 to 24 weeks postnatal) showed significantly decreased fluorescein leakage as a function of ageing $(P<0.05)$, which was accompanied by extensive capillary dropout as well as artherosclerotic vessels.

To compare pathological vascular changes, such as capillary nonperfusion, neovascularization, edema, hemorrhage, and retinal detachment, in Kimba and Akimba mice, each eye was arbitrarily divided into four quadrants with the dividing lines cutting at the optic nerve as shown in Figure 2A. The frequency of pathological features in the four quadrants of each eye was semiquantified. The results are summarized in Table 1. The frequency of microvascular abnormalities in young Akimba mice was very similar to aged Kimba mice. Capillary nonperfusion and neovascularization were most extensive in old Akimba mice. Retinal edema was detected in both young Kimba (20\%) and Akimba groups (67\%). The Akimba line not only had the majority of the young animals presenting with edema but the occurrence of edema was maintained in $36 \%$ of the old animals. Hemorrhages were only detected in some Akimba mouse eyes (data not shown), whereas retinal detachment was only seen in old Kimba and in young and old Akimba mice. In general, the pathological changes appeared earlier in Akimba mice and 
Table 1. Comparison of Retinal Vascular Changes in Kimba and Akimba Mice

\begin{tabular}{|c|c|c|c|c|}
\hline \multirow[t]{2}{*}{ Characteristic } & \multicolumn{2}{|c|}{ Kimba } & \multicolumn{2}{|c|}{ Akimba } \\
\hline & Young & Old & Young & Old \\
\hline \multicolumn{5}{|l|}{ Nonproliferative DR } \\
\hline Microaneurysms* & + & - & ++ & - \\
\hline Capillary nonperfusion ${ }^{\dagger}$ & ++ & +++ & ++ & ++++ \\
\hline Hemorrhage $e^{\ddagger}$ & - & - & + & + \\
\hline \multicolumn{5}{|l|}{$\begin{array}{l}\text { Microvascular } \\
\text { abnormalities }\end{array}$} \\
\hline Vascular leakages ${ }^{\S}$ & + & + & + & - पा \\
\hline Venous dilatation $^{\dagger}$ & +++ & ++ & ++ & $+\pi$ \\
\hline Venous loops $^{\dagger}$ & ++ & ++ & ++ & $+\pi$ \\
\hline $\begin{array}{l}\text { Tortuosity in retinal } \\
\text { vessels }^{+}\end{array}$ & ++ & ++ & ++ & $+\pi$ \\
\hline $\begin{array}{l}\text { Vessel constrictions/ } \\
\text { beading }^{\dagger}\end{array}$ & + & + & ++ & +++ \\
\hline \multicolumn{5}{|l|}{ Proliferative DR } \\
\hline Neovascularization" & & ++ & + & +++ \\
\hline Retinal edema** & $20 \%$ & $5 \%$ & $67 \%$ & $36 \%$ \\
\hline \multicolumn{5}{|l|}{ Advanced proliferative DR } \\
\hline Retinal detachment ${ }^{\ddagger}$ & - & + & + & + \\
\hline
\end{tabular}

*-, not present; + , less than five microaneurysms present; ++ more than five microaneurysms present.

${ }_{+}-$, not present; + , one quadrant; ++ , two quadrants; +++ , three quadrants; ++++ , four quadrants.

$\ddagger_{-}$, not present; + , present.

§Refer to fluorescein leakage grading (Figure 2)

"Extensive retinopathy/capillary dropout resulted in lower incidence of vascular features in the old Akimba mice

$\|_{+},<30 \%$ scanned area with neovascularization;,$++ 30 \%$ to $60 \%$ scanned areas with neovascularization;,$+++>60 \%$ scanned areas with neovascularization

${ }^{* *}$ Number of animals with edema per number of samples $\times 100$.

they were more severe in Akimba than in age-matched Kimba mouse eyes (Table 1).

\section{Retinal Morphology}

The histology of young and old mouse eyes is presented in Figure 5, A-H. The different retinal layers were well organized with no differences observed in young and old C57BI/6 mouse eyes (Figure 5, A and B). The monolayer of retinal pigment epithelial (RPE) cells (Figure 5, A and $\mathrm{B}$, arrowheads) separating the photoreceptor cell layer from the choroid was intact. Except for the slight thinning of the retina in old Akita mice, the histology of young Akita mouse eyes (Figure 5C) was very similar to young and old C57Bl/6 mouse eyes (Figure 5, A and B). In contrast, visible differences were seen in age-matched Kimba and Akimba mice (Figure 5, E-H). The obvious pathology in young Kimba and Akimba mice was the wavy photoreceptor cell layer (Figure 5, E and G), which often formed rosette structures (data not shown), and the transgression of retinal blood vessels from the inner retina into the normally blood vessel-free photoreceptor cell layers (Figure 5, E-G; arrows). Disturbance was also seen in the RPE cell layer and in some parts more than one layer of RPE cells was observed (data not shown). Breaks in the RPE cell layer were present in old Kimba and Akimba mice (Figure 5, $\mathrm{F}$ and $\mathrm{H}$; arrowheads; Figure 5F inset) at points where the new retinal vessels transgressed the RPE cell layer (Figure 5G inset, arrows; Figure 3, C and D arrows). The presence of new vessels in Figure $3 \mathrm{C}$ was
YOUNG MICE
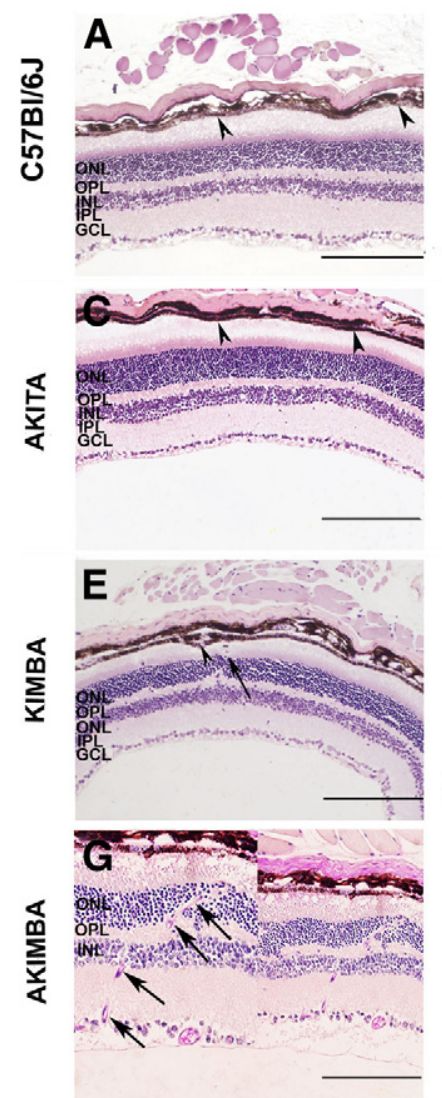

OLD MICE
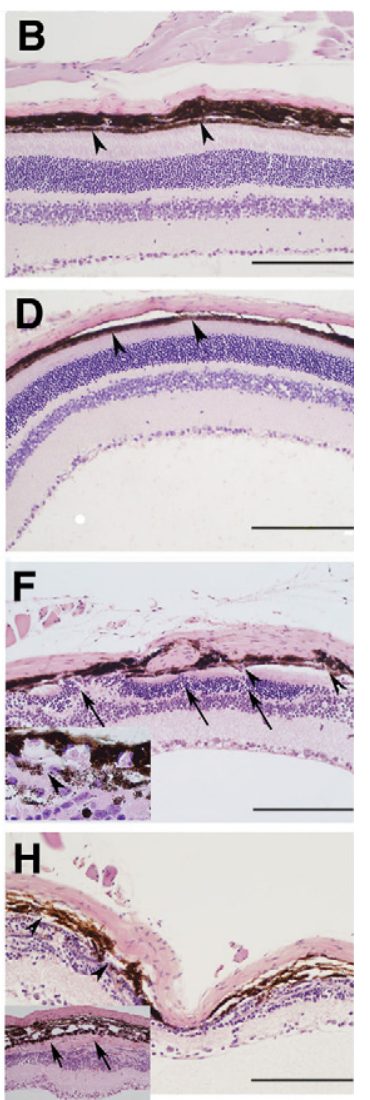

Figure 5. Light micrographs of paraffin-embedded eyes of young (A, C, E, and $\mathbf{G})$ and old (B, D, F, and $\mathbf{H}) \mathrm{C} 57 \mathrm{Bl} / 6$ (A and $\mathbf{B})$, Akita ( $\mathbf{C}$ and $\mathbf{D})$, Kimba $(\mathbf{E}$ and $\mathbf{F})$, and Akimba mouse eyes $(\mathbf{G}$ and $\mathbf{H})$. The sections were stained with H\&E $(\mathbf{A}-\mathbf{F}$ and $\mathbf{H})$ and PAS $(\mathbf{G})$. Scale bar $=165 \mu \mathrm{m}$. Arrowheads in A-D point to the intact monolayer of retinal pigment epithelial cells. Arrowheads in $\mathbf{E}, \mathbf{F}$, and $\mathbf{H}$ point to breaks in the retinal pigment epithelium of Kimba and Akimba mouse eyes. Arrows in E-G point to blood vessels transgressing the normally blood vessel-free photoreceptor cell layers, and arrows in $\mathbf{H}$ (inset) point to fibrotic layer. GCL, ganglion cell layer; INL, inner nuclear layer; IPL, inner plexiform layer; OPL, outer plexiform layer; and ONL, outer nuclear layer.

confirmed by staining a section 50- $\mu \mathrm{m}$ apart with the vascular stain biotinylated isolectin-IB4 (Figure 3D, arrows and arrowhead).

The severity of changes varied between eyes of mice of the same age and same genotype and even within the same eye. In some young Kimba and Akimba mice, there was severe loss of photoreceptors and thinning of the neural retina (data not shown) similar to changes common in the old mice (Figure 5, F and $\mathrm{H}$ ). In contrast, the neural retina appeared thicker and more swollen in some young Kimba mouse eyes (Figure 5E). The pathological changes in old Kimba and Akimba mice included reduction in photoreceptor layer thickness to complete loss of photoreceptors (Figure 5, F and $\mathrm{H}$ ), and replacement of photoreceptors and RPE cell layers by fibrotic tissue (Figure $5 \mathrm{H}$, inset, arrows). Compared with old Kimba mice, the old Akimba mice displayed similar but more severe retinal lesions (Figure $5 \mathrm{H}$ ) such as patchy loss of cells in the ganglion cell layer, reduced thickness of inner plexiform and inner nuclear layers, almost nonexistent outer plexiform layer, and presence of fibrotic tissue. In 
addition, the outer nuclear layer was almost completely destroyed, and the integrity of the RPE cell layer was compromised with blood vessels growing between the cells. Infiltration of pigmented cells into the neural retina was observed in some eyes (Figure $5 \mathrm{H}$ ). In young and old Akimba mice, there was an increase in blood vessels in the different layers of the retina and this was most pronounced in the outer nuclear layer (Figure 5G and Figure $3 \mathrm{C}$, arrows) where some of the vessels were also relatively enlarged.

\section{Localization of Immune Cells}

There was no difference between $\mathrm{MHC}$ class $\mathrm{II}^{+}$staining in young Akita mice (Figure 3E) and their age-matched C57BI/6 littermates (data not shown). In contrast, retinae from both age-matched Kimba (Figure 3F) and Akimba mice (Figure $3 G$ ) showed a dramatic rise in MHC class $\mathrm{II}^{+}$cellular staining throughout the retina. The majority of dendriform $\mathrm{MHC}$ class $\mathrm{II}^{+}$cells were organized into a network that spanned from the juxtapapillary area, across retinal venules, toward and including the peripheral retina (Figure $3 \mathrm{H}$, arrows). Variable quantities of smaller, round MHC class $\mathrm{II}^{+}$cells (Figure $\mathrm{H}$, arrowhead) were also observed. There was no obvious difference in the nature of $\mathrm{MHC}$ class $\mathrm{II}^{+}$cellular spread between young Kimba and Akimba mice. We did not find any evidence of endothelial or RPE staining for MHC class $\mathrm{II}^{+}$in any of the described models.

\section{Quantification of Morphological Changes}

The morphological changes in eyes of young and old mice, quantified based on the number of layers of photoreceptor cell nuclei, number of ganglion cells, and thickness of the neural retina, are presented in Figure 6, $\mathrm{A}-\mathrm{C}$. The number of layers of photoreceptor cell nuclei in young Akita mice $(13.8 \pm 0.7)$ was not significantly different from that of young C57BI/6 mice (14.3 $\pm 0.1 ; P>$ $0.05)$. In young Kimba mice, the mean number of layers of photoreceptor cell nuclei $(6.2 \pm 2.4)$ was significantly lower than those of young Akita $(P<0.01)$ or young C57BI/6 $(P<0.01)$ mice. Similarly, the mean number of layers of photoreceptor cell nuclei in young Akimba mice $(5.9 \pm 1.8)$ was significantly lower than that of young Akita $(P<0.01)$ or young C57BI/6 $(P<0.01)$ mice but was similar to that of young Kimba mice $(P>0.05)$. Except for Akimba mice, where the number of layers of photoreceptor cell nuclei continued to decrease with age from $6.0 \pm 1.8$ to $0.2 \pm 0.3(P<0.01)$, there were no significant age-dependent changes in the number of layers of photoreceptor cell nuclei in C57BI/6, Akita, and Kimba mice (Figure 6A).

There was no statistically significant ganglion cell loss in young Akita $(73.9 \pm 2.6)$ and Akimba $(72.0 \pm 0.2)$ mice, but significant loss of ganglion cells was observed in Kimba $(62.1 \pm 5.5)$ mice when compared with agematched C57BI/6 mice $(76.8 \pm 1.3 ; P<0.01)$. Significant age-dependent changes in ganglion cell number were seen in the Akita $(P<0.01)$, Kimba $(P<0.05)$, and
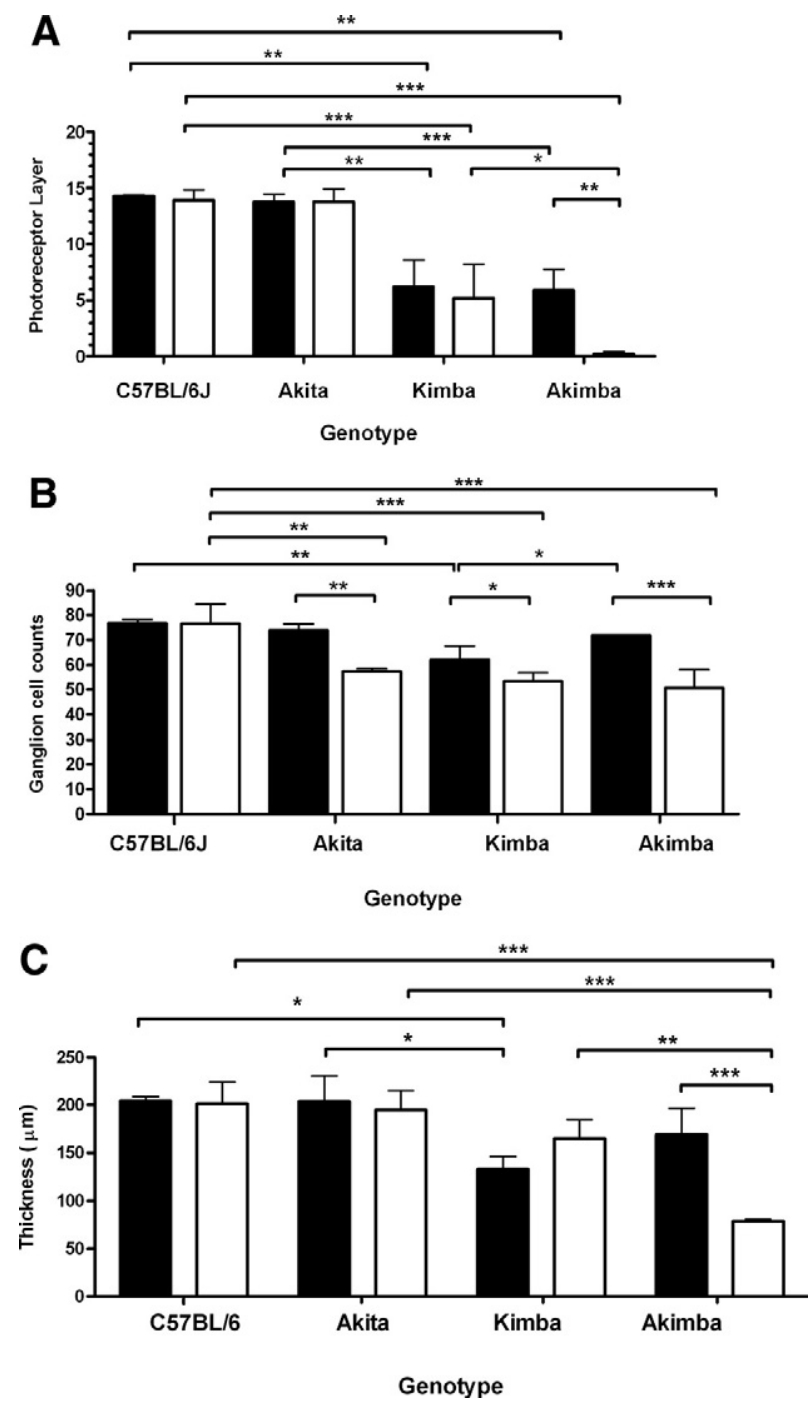

Figure 6. Graph showing mean photoreceptor layer thickness (A), mean number of ganglion cells over a $170-\mu \mathrm{m}$ linear distance $(\mathbf{B})$, and mean neural retina thickness (C) of young and old $\mathrm{C} 57 \mathrm{Bl} / 6$, Kimba, Akimba, and Akita mice. Black bars = young animals; white bars $=$ old animals. ${ }^{*} P<0.05$; ${ }^{* * *} P<$ $0.01 ;{ }^{* * * *} P<0.001$.

Akimba $(P<0.001)$ mice (Figure $6 \mathrm{~B})$. In the old age group, there were significantly fewer ganglion cells in the Akita $(57.4 \pm 1.1, P<0.01)$, Kimba $(50.8 \pm 7.1, P<$ $0.001)$, and Akimba (53.4 $\pm 3.5, P<0.001)$ compared with old $\mathrm{C} 57 \mathrm{BI} / 6(76.7 \pm 7.7)$ mice. The greatest agedependent loss in ganglion cell numbers (from $72.0 \pm 0.2$ to $53.4 \pm 3.5$ ) was observed in the Akimba mice.

The mean neural retinal thickness of young Kimba $(132.8 \pm 13.7 \mu \mathrm{m})$ was significantly lower $(P<0.05)$ than those of age-matched C57BI/6 (204.4 $\pm 4.4 \mu \mathrm{m}$; $P<$ $0.001)$ and Akita $(203.8 \pm 27.1 \mu \mathrm{m} ; P<0.001)$ mice (Figure 5C). A statistically significant age-dependent decrease in mean neural retinal thickness was seen in the old Akimba mice $(P<0.001)$ but not in the C57BI/6, Akita, or Kimba mice. The old Akimba mice had the thinnest neural retinal $(78.7 \pm 1.6 \mu \mathrm{m})$ of all four genotypes, representing the most severe age-dependent loss of photoreceptors and ganglion cells observed in this study. 


\section{Ocular mVEGF and hVEGF Levels}

In young Kimba and Akimba mice, there was no detectable hVEGF present. mVEGF levels were elevated in young Kimba (38.9 $\pm 10.3 \mathrm{pg} / \mathrm{ml})$, Akimba $(28.7 \pm 3.3$ $\mathrm{pg} / \mathrm{ml})$, and Akita $(29.3 \pm 11.2 \mathrm{pg} / \mathrm{ml})$ mice when compared with $\mathrm{C} 57 \mathrm{BI} / 6(20.5 \pm 7.0 \mathrm{pg} / \mathrm{ml})$, but the differences were not statistically significant $(P>0.05)$. Similarly, there were no statistically significant age-related or genotype-related differences $(P>0.05)$ in mean mVEGF levels between aged mice.

\section{Discussion}

Clinically, DR is a progressive disease that shows great variation between individuals. The earliest minor neuronal changes $^{23}$ eventually convert into nonproliferative DR (NPDR). NPDR might progress to vision-threatening proliferative DR (PDR) over decades of hyperglycemia if left untreated. ${ }^{24}$ The most crucial step in the disease process is the conversion of vascular abnormalities into PDR. PDR is known to be associated with up-regulated VEGF expression, ${ }^{25}$ which drives the proliferation of endothelial cells. VEGF injected into normal, nondiabetic eyes recapitulated many of the retinal vascular changes triggered by diabetes, such as intercellular adhesion molecule-1 up-regulation, leukocyte adhesion, vascular permeability and capillary nonperfusion, or dropout. ${ }^{26-29}$ Intercellular adhesion molecule-1 up-regulation is linked to increased leukostasis and retinal leukostasis is a very early event in DR with important functional consequences. Both retinal vascular leakage and capillary nonperfusion seem to follow its development. ${ }^{29}$ Hence, it is not surprising that VEGF up-regulation could result in retinal vascular changes and animal models with elevated VEGF levels in the retina ${ }^{17,30}$ have been informative and particularly useful for the development of new treatment strategies. ${ }^{17,31}$ However, these models have all been on a normoglycemic background, limiting their value in the study of DR.

Overall, the Akimba mice retained the key characteristics of the parent Akita (hyperglycemia) and Kimba (RNV) models. However, some significant differences between the parent strains and the new Akimba model were also noted. Surprisingly, BGL was significantly higher in young Akimba than in young Akita mice, but both genotypes reached similar BGL at $\geq 24$ weeks postnatal. Impaired or stalled growth, one of the features of severe, untreated hyperglycemia, was also observed in Akita ${ }^{2-4}$ and the new Akimba model, in which there was no weight gain over a period of 4 months. Clinical ophthalmic examination identified significant differences between the four different genotypes. Compared with the background strain, C57BI/6, no changes were detected in the Akita line by FA and OCT in young and old mice. However, significant vascular changes such as microaneurysm, leaky capillaries, venous beading, tortuous vessels, capillary dropout, and attenuation of vessels were observed in Kimba and Akimba mice (Table 1). The OCT was extremely useful for tracking the progression of edema over time (Table 1). The major difference between young
Kimba and Akimba mice was the much higher prevalence of edema in the young Akimba mice (Table 1). In humans, macular edema occurs when diffuse capillary and microaneurysm leakage at the macula causes the macular retina to swell with fluid. This complication of DR can occur at virtually any stage during DR development. Diabetic macular edema represents the leading cause of visual impairment in patients with diabetes ${ }^{32}$ and the available treatments are not always satisfactory. Edema was not only more frequent but persisted with increasing age in the Akimba mice, suggesting that the Akimba mice could be a useful model for the development of alternative treatments for this condition. These results suggest that hyperglycemia in combination with VEGF caused more severe or extensive neovascular damage and hence, the higher incidence of edema, which led to the more progressive retinal degeneration and fibrosis. As retinal edema is a major cause of diabetic retinal pathology and the major cause of blindness, the fact that the early transient expression of hVEGF in the presence of hyperglycemia leads to greater prevalence of retinal edema suggests a potential role for the casual up-regulation of VEGF in the development of edema in humans. The difference between Kimba and Akimba was not limited to the presence of edema and it became more pronounced with increasing age. The Kimba mice had neovascular changes similar to NPDR in humans by 8 weeks of age, but the vascular leakiness and other retinopathic changes remained relatively stable over time. In the Akimba mice, the retinopathic changes were more progressive (Figure 2). As measured by the presence of new vessels in OCT section scans, neovascularization in Akimba mice was more severe than in the Kimba mice (Table 1). In contrast to the Kimba mice, leaky blood vessels were not observed in the Akimba mice at 20 weeks postnatal (Figure 2, P and T; Figure 4B) due to massive capillary drop out/nonperfusion and atherosclerotic vessels. Total loss of the photoreceptor layer (Figure $6 \mathrm{~A}$ ) and a significant amount of fibrotic tissue were observed in the majority of the old Akimba mice (Figure $5 \mathrm{H}$ ).

Although almost all major features of NDPR and PDR were present, pre-RNV was not observed. The triggering mechanism for the development of pre-RNV is not well understood. A study using experimental rodents with hypoxia-induced neovascularization demonstrated newly formed blood vessels growing from the inner limiting membrane of the retina into the vitreous in response to hypoxia resulting in pre-RNV. ${ }^{33}$ The mouse models that develop pre-RNV display high density and evenly distributed retinal ganglion cells. Retinal ganglion cells are known to mediate vessel growth during an ischemic event by producing essential angiogenic factors such as VEGF. ${ }^{34}$ In our Kimba and Akimba model, our results demonstrated the loss of cells on the ganglion cell layer. In addition, fenestrations of new blood vessels in our mouse models grew toward the outer nuclear layer, where the source of VEGF production is the photoreceptors. These events could account for the absence of pre-RNV in the Akimba model.

Measurement of retinal thickness was used as an indicator of progressive retinal pathology in all four 
genotypes. Retinal thickness measurements using in vivo OCT and histology-based morphometry demonstrated that Kimba and Akimba mice had consistently thinner retinae when compared with age-matched young and old $\mathrm{C} 57 \mathrm{BI} / 6$ and Akita mice. Consistent with a progressive phenotype, the Akimba mice over time demonstrated a more severe loss of photoreceptors and thinning of the retina than Kimba mice.

Morphometric analysis of the Akita retinae confirmed the neuronal changes described previously ${ }^{5}$ in the absence of morphological vascular changes. This included significant ganglion cell loss and associated, though not significant $(P>0.05)$ thinning of the neural retina 20 weeks after the onset of hyperglycemia. These observations are in agreement with those made by using OCT in human subjects, which detected small changes in retinal thickness of diabetic patients with no or minimal DR in the absence of observable vascular changes. This suggests that neuronal loss may precede and ultimately contribute to the later development of vascular pathologies associated with $\mathrm{DR}$, eventually resulting in $\mathrm{RNV} .{ }^{23,35,36}$ In contrast to ganglion cell loss, but in agreement with the observations made in humans, the number of layers of photoreceptor cell nuclei was maintained in the old Akita mice. On the other hand, there was a surprising delay in ganglion cell loss in the Akimba line. Compared with young C57BI/6 mice, there was no statistically significant ganglion cell loss in young Akimba mice, whereas in old mice the number of ganglion cells was significantly reduced to levels similar to those in old Kimba or old Akita mice. The dynamics of ganglion cell loss in the Akimba mice were comparable with those seen in Akita rather than the Kimba mice. This was an unexpected observation suggesting that a neuroprotection gene may have been activated in the Akita line, resulting in delayed ganglion cell loss. Alternatively, the presence of elevated levels of hVEGF at a young age may have delayed the loss of neuronal cells in the Akimba mice. ${ }^{37,38}$ The neuroprotective effect of VEGF is well known, but we can only speculate at present whether elevated hVEGF levels, ${ }^{15}$ which were still present around the time of hyperglycemia onset, might have delayed ganglion cell death. The presence of hVEGF did not seem to delay ganglion cell loss in the young Kimba mice, suggesting that it is strictly associated with the genetics and/or physiological features of the Akita line.

We observed an increase in the incidence of edema in the retinal layers as well as the severity of neuroretinal (Figure 6) and vascular changes (Table 1; Figures 4 and 5 ) in the Akimba mice compared with the Kimba mice. This suggests that hyperglycemia may either play a role in exacerbating VEGF-driven neovascularization or it might amplify the retinal damage caused by the initial neovascularization. The Akimba mice presented the most important features of the Kimba and Akita mice, thus they could facilitate studies on the dual effects of transient VEGF up-regulation and hyperglycemia on retinal vascular changes. In humans, VEGF is known to be up-regulated from very early in DR, it is present at different levels as DR progresses, and is involved in the inflammatory response to diabetes. ${ }^{4,28,29,31,39-45}$ In the vitreous of pa- tients with PDR, VEGF concentrations can reach $\sim 1316$ $\mathrm{pg} / \mathrm{ml}$ and such high levels are associated with strong pathological changes. ${ }^{25,46}$ It has been understood for a long time that PDR is associated with elevated levels of VEGF, but more recently it has been proposed that the conversion of NPDR to PDR may involve additional pathological stimuli such as infections and inflammation. ${ }^{47}$ The short transient up-regulation of VEGF expression in the Kimba and Akimba mice resulted in significant neovascular changes suggesting that even transient VEGF upregulation in the human eye might be sufficient to initiate the progression of NPDR to PDR. The amount of evidence supporting a role for inflammation in the pathogenesis of DR is strong, but critical information relating to the relative importance, the relevant mechanisms, and the required kinetics remain to be elucidated. Although the pathogenesis of DR is not fully understood, DR has been reported to be a low grade inflammatory disease. ${ }^{39}$ The induction of $\mathrm{MHC}$ class II antigen expression is a common feature of various central nervous system pathologies, ${ }^{48}$ where blood-tissue barrier is acutely or chronically compromised. In the retina, the MHC II antigen appears to rise with the blood-retina barrier dysfunction secondary to (1) ageing, ${ }^{49}(2)$ range of pathologies, ${ }^{49,50}$ and (3) possible strain-specific variations in the integrity of retinal pigment epithelium (in mice). ${ }^{50}$ The findings of our study indeed conform to these notions: the hVEGF-mediated disruption of retinal vasculature as well as the RPE layer (Kimba and Akimba) drives abundant $\mathrm{MHC}$ class $\mathrm{II}^{+}$up-regulation, in this case demonstrable with dendriform and round $\mathrm{MHC}$ class $\mathrm{II}^{+}$cells surrounding the venules and saturating the juxtapapillary region and peripheral retina. This is contrary to what is seen in C57BI/6 and Akita mice, in which the morphological evidence of endothelial or RPE damage is absent. Furthermore, our results indicate that in a young mouse retina, hyperglycemia does not independently affect the pattern or the extent of staining for $\mathrm{MHC}$ class II antigen.

The peri-venular, but not peri-arteriolar, localization of $\mathrm{MHC}$ class $\mathrm{II}^{+}$cells in a context of experimental autoimmune uveitis-induced blood retinal barrier breakdown was recently pointed out by $\mathrm{Xu}$ et al..$^{50}$ Similar $\mathrm{MHC}$ class $\mathrm{II}^{+}$distribution in VEGF-related pathology suggests that peri-venular pattern of staining is not specific to the mechanism of injury, but is yet another marker of the blood-tissue barrier breakdown in mice. Finally, without functional studies, the retinal MHC class II patterning in Kimba and Akimba does not allow for further deductions about (1) the actual success of antigen presentation or (2) involvement of retinal autoimmunity in these models. In the absence of murine models of spontaneous PDR, Kimba and Akimba models provide a solid framework for further immunophenotyping of progressive retinopathy secondary to manipulations of VEGF or glycemic status.

Despite the presence of hyperglycemia, the neovascular changes seen in the Akimba mouse did not arise due to long-term hyperglycemia as in human DR. Unlike human DR, the transient up-regulation of VEGF in Kimba and Akimba mice is due to the presence of the transgene hVEGF $_{165}$ in the photoreceptors and not induced by vascular damage caused by prolonged hyperglycemia. This 
Akimba model is thus not suitable for studying the etiology of DR and the issues associated with the development of preretinal neovascularization. However, the neovascular processes and the associated damages are similar. Hence, the analysis of the Akimba mice might provide an important tool to improve our understanding of the complex processes that result in the development of DR. Further studies will be necessary to elucidate the mechanism of enhanced vascular and neuronal retinal changes, neuroprotection, and the role of inflammation in the Akimba mice.

In summary, while the Akimba mice retained hVEGFinduced retinal neovascularization and hyperglycemia, they also demonstrated changes that differentiated this new model from its parental Kimba and Akita genotypes. The combined presence of hyperglycemia and hVEGF appeared to hasten the development of abnormalities, such as higher BGLs in young Akimba mice, worsening KBW ratio, accelerated photoreceptor loss, more severe retinal vascular pathology, neovascularization, fibroses, and associated edema.

\section{References}

1. Hogan $P$, Dall T, Nikolov P: Economic costs of diabetes in the US in 2002. Diabetes Care 2003, 26:917-932

2. Izumi T, Yokota-Hashimoto H, Zhao S, Wang J, Halban PA, Takeuchi $\mathrm{T}$ : Dominant negative pathogenesis by mutant proinsulin in the Akita diabetic mouse. Diabetes 2003, 52:409-416

3. Oyadomari S, Koizumi A, Takeda K, Gotoh T, Akira S, Araki E, Mori M: Targeted disruption of the Chop gene delays endoplasmic reticulum stress-mediated diabetes. J Clin Invest 2002, 109:525-532

4. Wang J, Takeuchi T, Tanaka S, Kubo SK, Kayo T, Lu D, Takata K, Koizumi A, Izumi T: A mutation in the insulin 2 gene induces diabetes with severe pancreatic beta-cell dysfunction in the Mody mouse. J Clin Invest 1999, 103:27-37

5. Barber AJ, Antonetti DA, Kern TS, Reiter CE, Soans RS, Krady JK, Levison SW, Gardner TW, Bronson SK: The Ins2Akita mouse as a model of early retinal complications in diabetes. Invest Ophthalmol Vis Sci 2005, 46:2210-2218

6. Conaway HH, Brown CJ, Sanders LL, Cernosek SF, Farris HE, Roth SI: Spontaneous diabetes mellitus in the New Zealand white rabbit: history, classification, and genetic analysis. J Hered 1980, 71:179-186

7. Gerritsen GC, Dulin WE: Characterization of diabetes in the Chinese hamster. Diabetologia 1967, 3:74-84

8. Kramer JW, Nottingham S, Robinette J, Lenz G, Sylvester S, Dessouky MI: Inherited, early onset, insulin-requiring diabetes mellitus of Keeshond dogs. Diabetes 1980, 29:558-565

9. Lenzen S, Tiedge M, Elsner M, Lortz S, Weiss H, Jorns A, Kloppel G, Wedekind D, Prokop CM, Hedrich HJ: The LEW.1AR1/Ztm-iddm rat: a new model of spontaneous insulin-dependent diabetes mellitus. Diabetologia 2001, 44:1189-1196

10. Makino S, Kunimoto K, Muraoka Y, Mizushima Y, Katagiri K, Tochino $Y$ : Breeding of a non-obese, diabetic strain of mice. Jikken Dobutsu 1980, 29:1-13

11. Nakhooda AF, Like AA, Chappel Cl, Murray FT, Marliss EB: The spontaneously diabetic Wistar rat: metabolic and morphologic studies. Diabetes 1977, 26:100-112

12. Gastinger MJ, Kunselman AR, Conboy EE, Bronson SK, Barber AJ: Dendrite remodeling and other abnormalities in the retinal ganglion cells of Ins2 Akita diabetic mice. Invest Ophthalmol Vis Sci 2008 , 49:2635-2642

13. Lai CM, Shen WY, Brankov M, Lai YK, Barnett NL, Lee SY, Yeo IY, Mathur R, Ho JE, Pineda P, Barathi A, Ang CL, Constable IJ, Rakoczy EP: Long-term evaluation of AAV-mediated sFlt-1 gene therapy for ocular neovascularization in mice and monkeys. Mol Ther 2005, 12:659-668

14. van Eeden PE, Tee LB, Lukehurst S, Lai CM, Rakoczy EP, Beazley
LD, Dunlop SA: Early vascular and neuronal changes in a VEGF transgenic mouse model of retinal neovascularization. Invest Ophthalmol Vis Sci 2006, 47:4638-4645

15. Shen WY, Lai CM, Graham CE, Binz N, Lai YK, Eade J, Guidolin D, Ribatti D, Dunlop SA, Rakoczy PE: Long-term global retinal microvascular changes in a transgenic vascular endothelial growth factor mouse model. Diabetologia 2006, 49:1690-1701

16. Campochiaro PA: Retinal and choroidal neovascularization. J Cell Physiol 2000, 184:301-310

17. Lai CM, Dunlop SA, May LA, Gorbatov M, Brankov M, Shen WY, Binz N, Lai YK, Graham CE, Barry CJ, Constable IJ, Beazley LD, Rakoczy EP: Generation of transgenic mice with mild and severe retinal neovascularisation. Br J Ophthalmol 2005, 89:911-916

18. Lai CM, Estcourt MJ, Wikstrom ME, Himbeck RP, Barnett NL, Brankov M, Tee LB, Dunlop SA, Degli-Esposti MA, Rakoczy EP: rAAV.sFlt-1 gene therapy achieves lasting reversal of retinal neovascularization in the absence of a strong immune response to the viral vector. Invest Ophthalmol Vis Sci 2009, 50:4279-4287

19. Shen WY, Lai CM, Lai YK, Zhang D, Zaknich T, Sutanto EN, Constable IJ, Rakoczy PE: Practical considerations of recombinant adeno-associated virus-mediated gene transfer for treatment of retinal degenerations. J Gene Med 2003, 5:576-587

20. Han BG, Hao CM, Tchekneva EE, Wang YY, Lee CA, Ebrahim B, Harris RC, Kern TS, Wasserman DH, Breyer MD, Qi Z: Markers of glycemic control in the mouse: comparisons of 6-h- and overnightfasted blood glucoses to $\mathrm{Hb}$ A1c. Am J Physiol Endocrinol Metab 2008, 295:E981-E986

21. Ishida S, Usui T, Yamashiro K, Kaji Y, Ahmed E, Carrasquillo KG Amano S, Hida T, Oguchi Y, Adamis AP: VEGF164 is proinflammatory in the diabetic retina. Invest Ophthalmol Vis Sci 2003, 44:2155-2162

22. Verley FA, Grahn D, Leslie WP, Hamilton KF: Sex ratio of mice as possible indicator of mutation rate for sex-linked lethals. J Hered 1967, 58:285-290

23. Biallosterski C, van Velthoven ME, Michels RP, Schlingemann RO, DeVries JH, Verbraak FD: Decreased optical coherence tomographymeasured pericentral retinal thickness in patients with diabetes mellitus type 1 with minimal diabetic retinopathy. $\mathrm{Br} \mathrm{J}$ Ophthalmol 2007 , 91:1135-1138

24. Diabetic retinopathy study. Report Number 6. Design, methods, and baseline results. Report Number 7. A modification of the Airlie House classification of diabetic retinopathy. Prepared by the Diabetic Retinopathy. Invest Ophthalmol Vis Sci 1981, 21:1-226

25. Matsunaga N, Chikaraishi Y, Izuta H, Ogata N, Shimazawa M, Matsumura $\mathrm{M}$, Hara $\mathrm{H}$ : Role of soluble vascular endothelial growth factor receptor-1 in the vitreous in proliferative diabetic retinopathy. Ophthalmology 2008, 115:1916-1922

26. Detmar M, Brown LF, Schon MP, Elicker BM, Velasco P, Richard L, Fukumura D, Monsky W, Claffey KP, Jain RK: Increased microvascular density and enhanced leukocyte rolling and adhesion in the skin of VEGF transgenic mice. J Invest Dermatol 1998, 111:1-6

27. Lu M, Perez VL, Ma N, Miyamoto K, Peng HB, Liao JK, Adamis AP VEGF increases retinal vascular ICAM-1 expression in vivo. Invest Ophthalmol Vis Sci 1999, 40:1808-1812

28. Miyamoto K, Khosrof S, Bursell SE, Rohan R, Murata T, Clermont AC, Aiello LP, Ogura Y, Adamis AP: Prevention of leukostasis and vascular leakage in streptozotocin-induced diabetic retinopathy via intercellular adhesion molecule-1 inhibition. Proc Natl Acad Sci USA 1999, 96:10836-10841

29. Tolentino MJ, Miller JW, Gragoudas ES, Jakobiec FA, Flynn E, Chatzistefanou K, Ferrara N, Adamis AP: Intravitreous injections of vascular endothelial growth factor produce retinal ischemia and microangiopathy in an adult primate. Ophthalmology 1996, 103:1820-1828

30. Okamoto N, Tobe T, Hackett SF, Ozaki H, Vinores MA, LaRochelle W Zack DJ, Campochiaro PA: Transgenic mice with increased expression of vascular endothelial growth factor in the retina: a new model of intraretinal and subretinal neovascularization. Am J Pathol 1997, 151:281-291

31. Mori K, Duh E, Gehlbach P, Ando A, Takahashi K, Pearlman J, Mori K, Yang HS, Zack DJ, Ettyreddy D, Brough DE, Wei LL, Campochiaro PA: Pigment epithelium-derived factor inhibits retinal and choroidal neovascularization. J Cell Physiol 2001, 188:253-263

32. Ferris FL 3rd, Patz A: Macular edema: a complication of diabetic retinopathy. Surv Ophthalmol 1984, 28(Suppl):452-461

33. Feng $Y$, Wang Y, Pfister F, Hillebrands JL, Deutsch U, Hammes HP: 
Decreased hypoxia-induced neovascularization in angiopoietin-2 heterozygous knockout mouse through reduced MMP activity. Cell Physiol Biochem 2009, 23:277-284

34. Sapieha P, Sirinyan M, Hamel D, Zaniolo K, Joyal JS, Cho JH, Honore JC, Kermorvant-Duchemin E, Varma DR, Tremblay S, Leduc M, Rihakova L, Hardy P, Klein WH, Mu X, Mamer O, Lachapelle P, Di Polo A, Beausejour C, Andelfinger G, Mitchell G, Sennlaub F, Chemtob S: The succinate receptor GPR91 in neurons has a major role in retinal angiogenesis. Nat Med 2008, 14:1067-1076

35. Asefzadeh B, Fisch BM, Parenteau CE, Cavallerano AA: Macular thickness and systemic markers for diabetes in individuals with no or mild diabetic retinopathy. Clin Experiment Ophthalmol 2008, 36:455-463

36. Shimada Y, Li Y, Bearse MA Jr, Sutter EE, Fung W: Assessment of early retinal changes in diabetes using a new multifocal ERG protocol. Br J Ophthalmol 2001, 85:414-419

37. Gora-Kupilas K, Josko J: The neuroprotective function of vascular endothelial growth factor (VEGF). Folia Neuropathol 2005, 43:31-39

38. Kilic U, Kilic E, Jarve A, Guo Z, Spudich A, Bieber K, Barzena U, Bassetti CL, Marti HH, Hermann DM: Human vascular endothelial growth factor protects axotomized retinal ganglion cells in vivo by activating ERK-1/2 and Akt pathways. J Neurosci 2006, 26:1243912446

39. Adamis AP: Is diabetic retinopathy an inflammatory disease? $\mathrm{Br} J$ Ophthalmol 2002, 86:363-365

40. Amin RH, Frank RN, Kennedy A, Eliott D, Puklin JE, Abrams GW: Vascular endothelial growth factor is present in glial cells of the retina and optic nerve of human subjects with nonproliferative diabetic retinopathy. Invest Ophthalmol Vis Sci 1997, 38:36-47

41. Boulton M, Foreman D, Williams G, McLeod D: VEGF localisation in diabetic retinopathy. $\mathrm{Br} J$ Ophthalmol 1998, 82:561-568
42. Lutty GA, McLeod DS, Merges C, Diggs A, Plouet J: Localization of vascular endothelial growth factor in human retina and choroid. Arch Ophthalmol 1996, 114:971-977

43. Malecaze F, Clamens S, Simorre-Pinatel V, Mathis A, Chollet P, Favard C, Bayard F, Plouet J: Detection of vascular endothelial growth factor messenger RNA and vascular endothelial growth factor-like activity in proliferative diabetic retinopathy. Arch Ophthalmol 1994, 112:1476-1482

44. Pe'er J, Folberg R, Itin A, Gnessin H, Hemo I, Keshet E: Upregulated expression of vascular endothelial growth factor in proliferative diabetic retinopathy. $\mathrm{Br} J$ Ophthalmol 1996, 80:241-245

45. Shen WY, Yu MJ, Barry CJ, Constable IJ, Rakoczy PE: Expression of cell adhesion molecules and vascular endothelial growth factor in experimental choroidal neovascularisation in the rat. $\mathrm{Br} \mathrm{J}$ Ophthalmol 1998, 82:1063-1071

46. Murata T, Ishibashi $T$, Khalil A, Hata $Y$, Yoshikawa $H$, Inomata $H$ Vascular endothelial growth factor plays a role in hyperpermeability of diabetic retinal vessels. Ophthalmic Res 1995, 27:48-52

47. Knol JA, van Kooij B, de Valk HW, Rothova A: Rapid progression of diabetic retinopathy in eyes with posterior uveitis. Am J Ophthalmol 2006, 141:409-412

48. Perry $\mathrm{VH}$ : A revised view of the central nervous system microenvironment and major histocompatibility complex class II antigen presentation. J Neuroimmunol 1998, 90:113-121

49. Penfold PL, Liew SC, Madigan MC, Provis JM: Modulation of major histocompatibility complex class II expression in retinas with agerelated macular degeneration. Invest Ophthalmol Vis Sci 1997, 38:2125-2133

50. Xu H, Dawson R, Forrester JV, Liversidge J: Identification of novel dendritic cell populations in normal mouse retina. Invest Ophthalmol Vis Sci 2007, 48:1701-1710 